\title{
Study of the Levels of Serum Prolactin in Childhood Seizure Disorder
}

\author{
Dr.Rajeeva Mishra ${ }^{1}$, Dr.Bhardwaj Narayan Chaudhary ${ }^{2}$ \\ ${ }^{1 .} M D, D C H$, Associate Professor, Department Of Pediatrics and Neonatology, RIMS, Ranchi. \\ 2. Junior Resident (Academic), Dept. of Pediatrics and Neonatology, RIMS, Ranchi.
}

\begin{abstract}
:
Background: Seizure disorder is the most common neurological problem in children.Prolonged Seizure activity leads to failure of cerebral auto regulation.

Objective: This study aimed to determine the role of Serum Prolactin level in different type of Seizures and Seizure like activity in children, and correlate with the post-ictal duration.

Materials and Methods: This study was carried out in the department of Pediatrics and Neonatology, RIMS, Ranchi from March 2015 to September 2016. The present study was done on 75 cases of study group and 25 cases of control. The study group was divided into three groups of 25 cases each: Group I: (Generalised Tonic Clonic Seizures, Complex Partial Seizure, or Simple Partial Seizure).Group II: (Febrile Convulsion).Group III : (conditions mimicking seizures).Blood was collected within 2 hours of seizure and prolactin levels assayed. Results: Prolactin levels were significantly high only within Group I .Prolactin levels highest attained within 10 minutes and baseline levels were attained by 100 minutes. But in other group prolactin level was within normal limit.

Conclusion: The clinical usefulness of post-ictal prolactin estimation is restricted to the positive diagnosis of epileptic seizures. A high Prolactin level within 100 minutes of a seizure is suggestive of GTCS, or Complex partial seizure having occurred.
\end{abstract}

Keywords: Prolactin, Seizures.

\section{Introduction}

Seizure disorder is the most common neurological problem in children.Prolonged Seizure activity leads to failure of cerebral auto regulation. EEG in paediatric patient is extremely difficult in struggling child, and sedation in these children may lead to changes in character of waves and interpretation of EEG is difficult due to variability of waves. Here comes the probable role of serum prolactin level after epileptic seizures. We will analyse that serum prolactin level can be used as a biochemical marker for the diagnosis of seizure disorder.

\section{Aims And Objectives}

1) To determine the role of serum prolactin level as a biochemical marker in seizure disorders.

2) To find out whether serum prolactin can be used to differentiate between various types of epileptic seizures, febrile convulsions and seizure like events in children.

\section{Materials and Methods}

The study was conducted in admitted patients in pediatrics department of RIMS, Ranchi, aged between 6 months to 16 years of either sex. The estimation of serum prolactin levels were carried out by laboratories in the department of biochemistry, RIMS, Ranchi.

Selection of the cases for study group: - The cases were divided into four groups, each having 25 members. Group 1- Consisted of cases with Generalized Tonic Colonic Seizure, Complex Partial Seizure and Simple Partial Seizure.

Group 2- Consisted of typical febrile convulsion.

Group 3- Consisted of conditions mimicking seizures.

Group 4- Control group, admitted for reason other than fever and seizure.

\section{Methodology}

Blood was collected after venepuncture of ante-cubital vein using a no. 22 scalp vein needle and it was allowed to drip directly into a sterilized test tube. About $1 \mathrm{ml}$. of blood was collected, within two hours of occurrence of seizures. The exact interval between episodes of seizure and time of blood sample was noted. After one hour, the serum was separated and transferred to centrifuge tube. Then it was for 10 minutes at 2500 RPM and the serum was transferred using pasture disposable pipettes to capped vials and stored until analysis at deep Freeze. Serum prolactin estimation was done by chemiluminescence method. 


\section{Results}

1. Blood was collected within 2 hours of the seizure and serum prolactin levels were assayed. The following results were made:-

2. Among epileptic seizures, Generalized Tonic Colonic Seizure (60\%), Complex Partial Seizure (20\%) and Simple Partial Seizure (20\%) had significantly elevated level of serum prolactin.

3. Among the cases of conditions mimicking seizures, the incidence increased gradually with advancement of age with maximum incidence in female. The mean serum prolactin level was within normal limit.

4. The mean serum prolactin level in the control group was within normal limit.

5. The mean post-ictal prolactin level in cases with febrile convulsion was again within normal limit.

6. The mean post-ictal prolactin level in cases with epileptic seizures was above the normal limit.

7. Serum Prolactin was seen to be raised in cases of GTCS \& CPS. The sensitivity \& specificity of raised serum Prolactin in diagnosis of epileptic seizure was $64 \%$ and $98 \%$ respectively.

8. The mean Prolactin level was high in the case with GTCS (80\%) and CPS (60\%). The mean Prolactin level in present study in cases of GTCS was $37.27 \mathrm{ng} / \mathrm{ml}$ and in CPS was $31.44 \mathrm{ng} / \mathrm{ml}$. only one case, out of five with SPS was associated with increased Prolactin. The mean prolactin level in SPS was $17.99 \mathrm{ng} / \mathrm{ml}$.

\section{Figures and Tables}

Table: Serum Prolactin Level In Different Seizure Types

\begin{tabular}{|c|c|c|c|c|c|c|c|c|c|}
\hline \multirow{3}{*}{ Age Group } & \multicolumn{3}{|l|}{ GTCS } & \multicolumn{3}{|l|}{ CPS } & \multicolumn{3}{|l|}{ SPS } \\
\hline & \multirow{2}{*}{$\begin{array}{l}\text { No. of } \\
\text { Cases }\end{array}$} & \multicolumn{2}{|l|}{$\begin{array}{l}\text { Prolactin Level } \\
\text { (ng/ml) }\end{array}$} & \multirow{2}{*}{$\begin{array}{l}\text { No. of } \\
\text { Cases }\end{array}$} & \multicolumn{2}{|c|}{$\begin{array}{l}\text { Prolactin Level } \\
(\mathrm{ng} / \mathrm{ml})\end{array}$} & \multirow{2}{*}{ No. of Cases } & \multicolumn{2}{|c|}{$\begin{array}{l}\text { Prolactin Level } \\
(\mathrm{ng} / \mathrm{ml})\end{array}$} \\
\hline & & Range & Mean & & Range & Mean & & Range & Mean \\
\hline 6 mo. -4 yrs. & 1 & 33.32 & 33.32 & 2 & $\begin{array}{l}22.12- \\
36.48 \\
\end{array}$ & 29.3 & - & - & - \\
\hline 4 yrs. -8 yrs. & 2 & $36.62-38.46$ & 37.54 & 1 & 39.89 & 39.89 & 2 & $13.3-16.72$ & 15.01 \\
\hline 8 yrs. -12 yrs. & 6 & $20.20-51.5$ & 33.47 & 1 & 22.2 & 22.2 & 3 & $9.32-30$ & 19.88 \\
\hline 12 yrs.-16 yrs. & 6 & $22.19-56.5$ & 37.96 & 2 & 36.6 & 36.6 & - & - & - \\
\hline
\end{tabular}

Table: Frequency (Percentage) of increased Prolactin level in different seizure types

\begin{tabular}{|l|l|l|l|}
\hline \multirow{2}{*}{ Prolactin } & Seizure Types & \multicolumn{3}{|l|}{} \\
\cline { 2 - 4 } & GTCS & CPS & $1(20)$ \\
\hline Increased & $12(80)$ & $3(60)$ & $4(80)$ \\
\hline Normal & $3(20)$ & $2(40)$ & \\
\hline
\end{tabular}

Table: Corelation Between Post-ictal Prolactin Level and Post-ictal duration

\begin{tabular}{|c|c|c|c|c|c|c|}
\hline \multirow{4}{*}{$\begin{array}{l}\text { POST-ICTAL } \\
\text { DURATION } \\
\text { (min.) }\end{array}$} & \multicolumn{6}{|c|}{ SEIZURE TYPE } \\
\hline & \multicolumn{2}{|c|}{ GTCS } & \multicolumn{2}{|l|}{ CPS } & \multicolumn{2}{|l|}{ SPS } \\
\hline & \multicolumn{2}{|c|}{ PROLACTIN LEVEL } & \multicolumn{2}{|c|}{ PROLACTIN LEVEL } & \multicolumn{2}{|c|}{ PROLACTIN LEVEL } \\
\hline & Range & Mean & Range & Mean & Range & Mean \\
\hline $15-30$ & $31.46-38.64$ & 35.84 & 36.6 & 36.6 & $9.32-16.72$ & 13.22 \\
\hline $30-45$ & $20.2-39.0$ & 29.6 & $22.2-39.89$ & 32.85 & ---- & ---- \\
\hline $45-100$ & $21.6-36.62$ & 29.11 & 22.12 & 22.12 & ---- & ---- \\
\hline
\end{tabular}

Histogram showing Serum Prolactin Level in Different Seizure Types

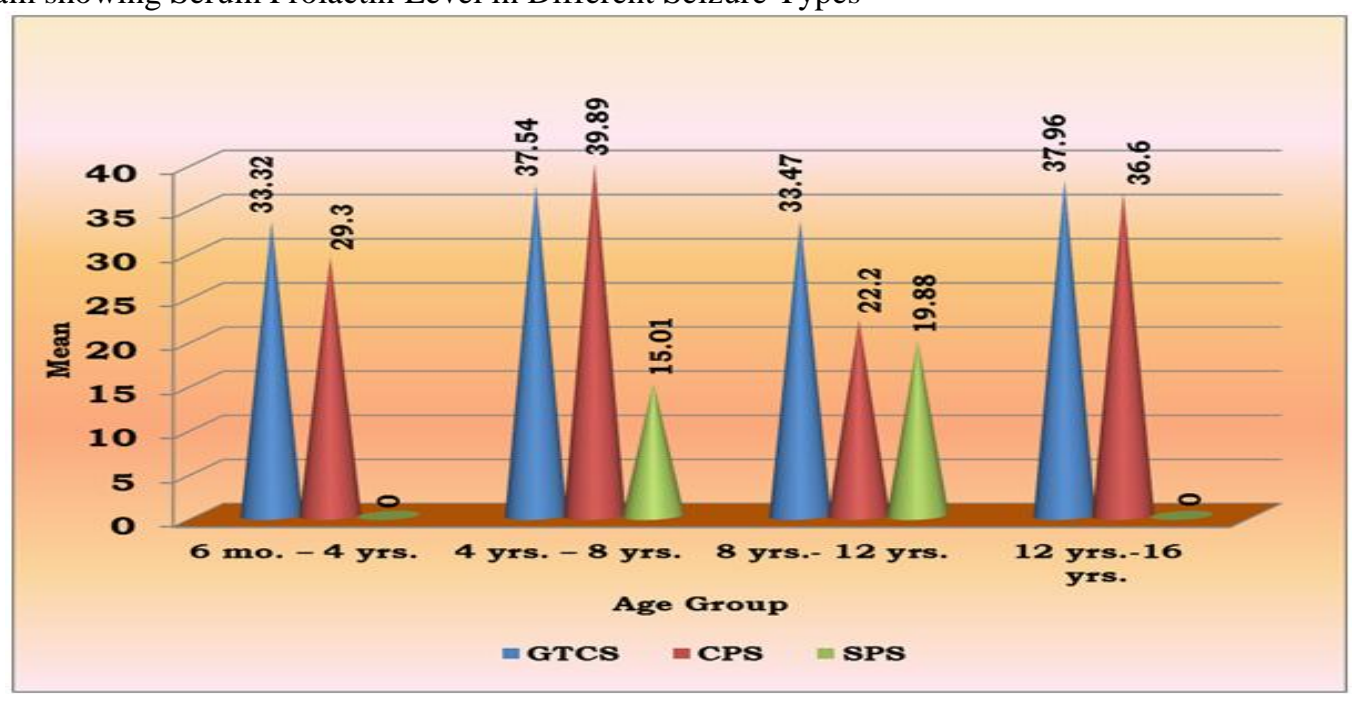




\section{Conclusion}

The clinical usefulness of post-ictal prolactin estimation is restricted to the positive diagnosis of epileptic seizures. A positive result is suggestive of GTCS, or Complex partial seizure having occurred. Although it cannot be used exclusively for differentiation between subtypes of epileptic seizures, yet it can easily be applied in cases of diagnostic uncertainly between epileptic and non-epileptic events, before submitting our poor patients to more sophisticated and expensive investigations. The maximum level was seen in cases in which blood sampling was done in 15 minutes of seizure. The mean level of Prolactin gradually decreased with the lapsed time between seizure and blood sampling. The cases in which sample were taken after 100 minutes were seen to be having normal post-ictal prolactin.

\section{References}

[1]. Nelson Textbook of Pediatrics, 2016-20 $0^{\text {th }}$ edition.

[2]. King DW, Gallagher BB, Murvin AJ, Smith DB, Marcus DJ, Hartlage LC, et al. Pseudoseizures: Diagnostic evaluation. Neurology . 19823.

[3]. Escueta A, Bascal F, Treiman D. Complex partial seizures on closed circuit television and EEG. Ann Neurol. 1982;292-300.

[4]. Trimble MR. Serum prolactin in epilepsy and hysteria.Br Med J 1978;1682.

[5]. Aninoff M.J (1992):Electrodiagnosis in clinical neurology: $3^{\text {rd }}$ edition. $1984 ; 107: 569-578$.

[6]. Jeavons PM. The practical management of Epilepsy.1975;1:11-14.

[7]. Pritchard PB, Wannamaker BB, Sagel J, Daniel CM, Serum Prolactin and Cortisol levels in evaluation of Complex Partial Seizure. Ann Neurol 1983; 14; 27-32. 